\title{
The formation of Christian theology in Alexandria
}

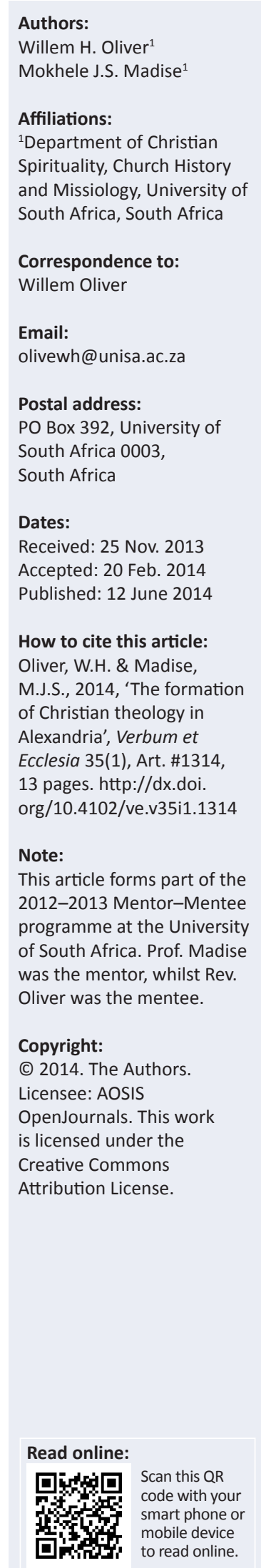

Jesus was born in Palestine. He was the main determinant for the foundation of a religious movement or sect later called Christianity. This movement, founded in Palestine after the ascension of Jesus, with Jerusalem as its main centre of worship, was merely a JudaeoChristian sect. In Jerusalem, the adherents to this movement were not really distinctive from the Jewish religion, as they worshipped the same God, Yahweh, went to the same Temple and/or synagogues and kept the same Jewish Laws. After the destruction of the Temple in $70 \mathrm{CE}$, many Jews, including the 'believers in Christ's teachings' (the earliest Christians) fled Jerusalem for different parts of the Roman Empire such as Transjordan, Syria and Africa. Different 'Christianities' developed in the main cities of the Roman Empire - Rome, Antioch and Alexandria. In each of these cities, the believers in Christ's teachings developed their own religion alongside Judaism. This article argued that it was in Alexandria, a world famous city during the time of the Roman Empire, especially renowned for its academic excellence, that the new religion best found and made its own stand. The Catechetical School, with scholarly heads and writers, such as Clement and Origen, started to develop a theology that set the standard for Christian theology in the Empire.

Intradisciplinary and/or interdisciplinary implications: The general assumption is that Jerusalem, as the origin of Christianity, was the place where it had its formation. This article proposed that it was actually Alexandria where Christianity was best found and became distinctive from Judaism. However, a lack of original sources on this subject area limited the research.

The greatest secret Africa has never told and Christian Europe has been seeking to conceal for the past two thousand years is the African origin of the concepts, doctrines, sacramental practices of religion, and the documents that became the foundation of Christianity in Europe. (Darkwah 2005:backpage)

\section{Introduction}

Africa, and more specifically Egypt as part of the Eastern region of the Roman Empire, is more than oft neglected as a source of intelligence and academic knowledge in the world. This also includes a reference to early Christianity in Alexandria, as well as the setting of Christian theology in Egypt. These characteristics are mostly allotted to the West, to Europe, specifically Rome, with Antioch not far behind. Quite a few scholars, such as Darkwah (2005), Oden (2007), Pheko (1982), Schaff (1910) and Stanley (1883), argued to the contrary and stated that Christianity found its first real feet in Africa. This has been acknowledged by Stanley (1883:56) when he stated in his Lectures on the Eastern Church that the field of Eastern Christendom is a comparatively untrodden field. He therefore called on his hearers to enlarge their petty Occidental (Western) horizon and to acknowledge the Eastern Apostolic Churches as the main stem of Christendom, of which the church of Rome itself was for 300 years a mere colony, unfelt in theology except by contributions to the Greek literature of Christians (cf. Schaff 1885b:4). Stanley (1883:66) expressed himself as follows: 'She [referring to Africa] is the mother, and Rome the daughter.'

Some of the reasons for this negligence are that many of Africa's sources are or were oral sources and therefore not readily accessible to researchers (ancient and modern), or because a tremendous amount of her academic sources was destroyed. For the past few centuries, Africa was only seen as the victim of colonisation, who inherited her religion from Europe. These anomalies were still accepted in the previous century, but now, in the 21st century, Africa is slowly but surely awakening and preparing herself to take her rightful stand in the world and in academia.

This article intends to contribute to the discussion on Africa (specifically Egypt, with Alexandria as main centre) as foundation for the theology of Christianity. The aim is to highlight Alexandria as the place where Christianity (qua Christianity - Fogarty 2004:33) was first formalised. It was here that the translation of the Jewish Scriptures into Greek (creating the Septuagint) took place 
and here that Clement and Origen wrote the first theology (or theologies) of Christianity, apart from the Bible. The article is written as a positive reaction on Thomas C. Oden's (2007) book, How Africa shaped the Christian mind, and especially on the following statement:

Many African Christians today have a deep conviction that they must think in terms that are indigenously African because this is what has been most neglected. That is a valid concern. Christianity meets the criterion of indigenous or traditional African religion, since it has twenty centuries of sustained presence in Africa ... The hunger to reunite the ancient and modern visions of Christianity is growing in Africa ... The recovery of African Christianity seeks both its own unique identity and to be at the same time a full participant in the whole of world Christianity. (Oden 2007:93)

Concerning the formation of Christianity, Oden (2007) made the following statement at the beginning of his book:

Africa played a decisive role in the formation of Christian culture. Decisive intellectual achievements of Christianity were explored and understood first in Africa before they were recognized in Europe, and a millennium before they found their way to North America. Christianity has a much longer history than its Western and European expressions. The profound ways African teachers have shaped world Christianity have never been adequately studied or acknowledged, either in the Global North or South ... Christianity would not have its present vitality in the TwoThirds world without the intellectual understandings that developed in Africa between 50 and 500 CE. This is a fact that has been ignored by scholars during the past five centuries ... The seed spread from Africa north. (pp. 9-10)

Oden (2007:26) added to these that, contrary to those who believe that Christian theology was imported from Europe to Africa, the ecumenical consensus was largely defined in Africa. That actually makes Europe indebted to Africa and not vice versa.

\section{This article attempts to argue that:}

- Although Christianity had its roots (origin) in Palestine, more specifically in Jerusalem, it only operated there as a sect of Judaism. Although the Jews were opposed to the believers in Christ's teachings in Jerusalem, the latter were none other than Jews themselves (Fogarty 2004:abstract), just adding one main ('schismatic') element to their faith, namely Jesus, coupled with the elements of his ascension and redemptive powers.

- Although the books of the New Testament (as we have them today) were written elsewhere, Alexandria was the most important root for the theology of Christianity and that it spread from there to the rest of the Roman Empire, that is, the known parts of Africa, Asia and Europe.

\section{Methodology}

The research in this article was conducted with an historical perspective as its basis and is related to the following definition of Abrams (1993):

... history in itself is not a set of fixed, objective facts but, like the literature with which it interacts (or, more precisely, like the literature which interacts with $i t)$, a text which needs to be interpreted; that a text, whether literary or historical, is a discourse which, although it may seem to present, or reflect, an external reality, in fact consists of what are called representations - that is, verbal formations which are the 'ideological products' or 'cultural constructs' of a particular era; and that these cultural and ideological representations in texts serve mainly to reproduce, confirm, and propagate the power-structures of domination and subordination which characterize a given society. (p. 249)

Busha and Harter (1980:91) detailed six steps for conducting historical research:

- The recognition of an historical problem or the identification of a need for certain historical knowledge.

- The gathering of as much relevant information about the problem or topic as possible.

- If appropriate, the forming of hypotheses that tentatively explain relationships between historical factors.

- The rigorous collection and organisation of evidence and the verification of the authenticity and veracity of the information and its sources.

- The selection, organisation and analysis of the most pertinent collected evidence and the drawing of conclusions.

- The recording of conclusions in a meaningful narrative.

Historical research also encompasses research concerning the origin, development and influence of ideas of the past. This is research based on engagement with the past. It includes investigations, such as the recording, analysis and interpretation of events in the past, in order to better understand it.

The way in which these elements work together in the research process used in this article is evident in Figure 1. This article had one main hypothesis and that was to indicate the importance of Africa, more specifically Egypt and

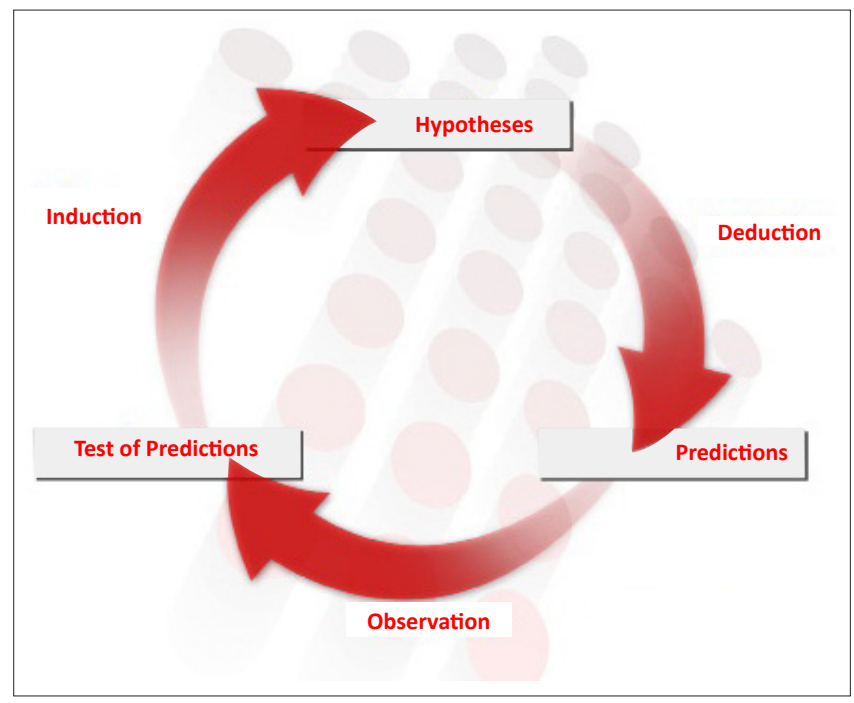

Source: Adapted from Blakstad, O., 2008, Research methodology: Key concepts of the scientific method, viewed 07 September 2012, from http://www.experiment-resources. com/research-methodology.html

FIGURE 1: Historical research methodology. 
Alexandria, as the place where Christian theology was formalised and from where it found its way to the rest of the Roman Empire. Careful research led to testing this prediction and the formulation of a conclusion based on this hypothesis.

\section{Discussion of specific concepts}

\section{'Africa' and 'Egypt'}

During the time of the Roman Empire, (the known part of) Africa did not have a collective name but was divided into provinces, each with a different name. Egypt was earlier known as Keme (the black land - alluding to the rich mud from the Nile inundations) and later, in the Old Testament times, as Mişra(j)im (cf. Bennett 1971:488-489). For the purposes of this article, we will refer to 'Africa' and 'Egypt', without engaging in deeper discussion about these names.

\section{Believers in Christ's teachings}

The phrase is borrowed from Fogarty (2004:101) and refers to the earliest Christians; in this article these believer's are also referred to as 'followers of Jesus'. The earliest Christians never referred to themselves in this way, as they also did not refer to themselves as Christians (cf. McGrath 2013:1-2). Fogarty (2004) stated:

\begin{abstract}
... that 'Christianity', for at least the $1^{\text {st }}$ century C.E., and possibly into the $2^{\text {nd }}$ century, is a misnomer, for the early followers of Jesus did not call themselves 'Christians'. Acts 11:26 records that '... it was in Antioch that the disciples were first called "Christians", but the text is in the passive tense, suggesting the term was attributed to the disciples (by others); it does not indicate that they used the term amongst themselves. (p. 101)
\end{abstract}

Robert Eisenman (1996:11) added to this that even 'if the testimony of Luke in Acts is to be credited', the 'Christians' in Palestine would not have been called by that name. He referred to Epiphanius' Adversus Haereses 29.1 and 29.4 where the followers of Jesus in Palestine were called 'Jessaeans, because their teaching arises from Jesus and they became his disciples'. In this passage, Epiphanius was referring to the 'Essenes'. This can be taken as proof that the term 'Christian' was not in general use during the 1st century. The majority of the believers in Christ's teachings were still Jews in all respects - ethnically as well as religiously - whilst observing the Jewish customs and traditions. Only one major element, amongst other less important ones, was added to their belief system and accepted in their teachings: Christ was the longawaited Messiah (cf. Fogarty 2004:101).

\section{Judaism}

Whilst the call of Abraham could be regarded as the introduction to Judaism, it actually started off with the Babylonian Exile (after the Roman destruction of the Temple in Jerusalem in $587 \mathrm{BCE}$ ). For the period up to $70 \mathrm{CE}$ (depicting the Roman destruction of the Second Temple and dispersal of most of the Jews into the Diaspora), 'the term is best used only for those elements which are either modifications or extensions of Old Testament concepts' (Ellison 1978:670). After $70 \mathrm{CE}$, a new Judaism was formed, knowing that the temple state had ceased forever (Fogarty 2004:47).

\section{Nilotic}

Oden (2007) defines this term as follows:

Nilotic is the family of languages that developed along the Nile long before Judaism and Christianity came to Egypt. These were interior African languages largely unaffected by Mediterranean cultures. They became the major linguistic vehicles for grassroots Christianity in the middle Nile valley. (p. 21)

\section{Roman Empire}

Three continents constituted the biggest part of the Roman Empire, namely Africa, Europe and Asia. Africa was the part of the Empire south of the Mediterranean. The historic cultures known in ancient North Africa were the Nilotic, Berber, Libyan, Numidian, Nubian and Ghanaian peoples. Europe constituted that part of the Empire north and west of the Straits of Byzantium, 'from Thrace to Ireland, from Sicily to Scandinavia' (Oden 2007:17). Asia, the third continent, constituted Palestine, Syria, Anatolia and the countries to the east. A world city represented each of these three continents: Rome in Europe, Antioch in Asia and Alexandria in Africa.

\section{Sect}

A sect occurs as a result of a schism within a conventional religious body when persons desiring a more otherworldly version of the faith break away to 'restore' the religion to a higher level of tension with its environment (Stark 1997:33). This term refers to a dissenting or schismatic religious body, especially one regarded as extreme or heretical in the ancient times (cf. Merriam-Webster n.d.).

\section{Three Jewish-Roman wars}

The First Jewish-Roman War was called 'The Great Revolt' (66-70[73] CE), the second war was the 'Kitos War' in 115-117 CE and the third was the 'Bar Kochba Revolt' of 132-135 CE.

\section{Two-Thirds world}

This term has been used mostly by evangelical Christians since the early 1980s to indicate the two-thirds of the world living in poverty (cf. eAlmanac n.d.).

\section{The first references to 'Christianity' Antioch}

According to Pearson (1997:11), the 'very first recorded instances' of the term 'Christianity' occurred in three Epistles written by Bishop Ignatius of Antioch in c. 90-110 CE, namely to the Magnesians 10:1 and 3, to the Philadelphians 6:1 and to the Romans 3:3. These formed part of his seven letters (Epistles) that he addressed to different churches - 'ekklesiai' in his time (cf. Georgi 1995:39), referred to in Acts 11:26. The term 'Christianity' was therefore coined for the first time in the 2nd century. During the 1st century most of the theology of the Christians was not noted. There were only a few copies of the Gospels and of Paul's letters, therefore their teachings were spread mostly by oral exchange, for example at gatherings for prayer. Ignatius of Antioch, however, observed that there was a 'new religion' emerging and he therefore gave it a proper name. 


\section{Alexandria}

The Epistle of Barnabas was reportedly the oldest complete Christian writing with its origin in Alexandria (Frend 1992:37), dating between 80 and 120 CE, most probably at the beginning of the reign of Hadrian - c. 117 CE (Pearson 1986:211). This Epistle described both the Jewish and Christian exegetical traditions in Alexandria (Pearson 1986:212). Barnard (1966:47) proposed that the author was a Jewish Rabbi converted to Christianity, who brought the Jewish exegetical and homiletical traditions of the Alexandrian synagogue with him.

By the time of the final redaction of Barnabas (c. $117 \mathrm{CE}$ ), just after the Revolt, relations between Christians and Jews had come to a breaking point in Alexandria as they still remembered the aftermath of the destruction of the Temple in $70 \mathrm{CE}$ and the excommunication of Christians from the synagogues. Barnabas referred to Christians as the new people of the Covenant', and the Jews as 'the former people' (e.g. Barn 5:7; 7:5; 13:1-6) (cf. Pearson 1986:213-214).

\section{The first years of Christianity Christianity in Jerusalem}

Jerusalem was the capital city of Israel from the time of King David in c. 1000 BCE. After King Solomon's death in c. 930 BCE, the unity of Israel (i.e. the northern and southern kingdoms) was terminated, mainly because of political instability in the northern kingdom. The northern kingdom, constituting the two 'states' of Galilee (north) and Samaria (south), with its capital being the city of Samaria, was influenced considerably by the Canaanite-Phoenician culture, whilst worship of Yahweh was only weekly presented in important circles (Fogarty 2004:46). The southern kingdom, Judah, kept Jerusalem as its capital city. This kingdom enjoyed a stable political, cultural and religious regime for the next 400 years, governed by descendants of David. According to Otzen (1998:8), Yahwism was developed in the kingdom of Judah to such an extent that it would determine the later Jewish understanding of worship and belief in the God of Israel, called Yahweh.

The northern kingdom was conquered by Assyria in 722 BCE, whilst Babylon captured the southern kingdom and destroyed the Temple in Jerusalem in 587 BCE. After the Babylonians were conquered by the Persians, the exiled Judaeans were free to remain in Babylon or return to Palestine - c. 540 BCE and afterwards. Otzen (1998:11) stated that the majority probably remained, in due course forming the Eastern Jewish Diaspora. A core group returned to Judah over a period of time, where they rebuilt the Temple, completing it in 516 BCE. These Judaeans enjoyed the protection of the Persian monarch and were left in peace for the ensuing centuries of Persian rule, thus allowing for consolidation of the community and of their religious beliefs (Fogarty 2004:46). The Judaeans living in Syria were less happy under Seleucid rule. They staged a successful rebellion (the Maccabean Revolt) against the Seleucids in the mid-160s BCE. Their success was later to inspire Jewish zealots who were impatient with the Roman rule in Jerusalem.

Then, in c. 6 BCE, Jesus was born a Jew in Bethlehem, close to Jerusalem, in Judah, under the power and rule of, and therefore as part of, the Roman Empire. His parents lived in Galilee. Shortly after his birth, his parents had to flee their country and they chose to flee to Egypt in Africa. As Egypt had already acted as homeland to the people of Yahweh in the days before Christ (when the Hebrews resided in Egypt from c. 1871 BCE for approximately 400-430 years - cf. Schneider 2009), now, almost two millennia later, Egypt once again acted as home to Yahweh's people, this time to Jesus and his fleeing parents. They stayed there for almost 4 years. The Son of God spent his first years in Africa! Jesus' parents then took him back to Galilee where he grew up.

In Jesus' time, Jerusalem was the main centre of Judaism, with the Temple as the focal point of their religion. Whilst Jerusalem was equipped with the Temple and synagogues, all the other cities and towns in Palestine only had synagogues. Jesus interpreted the Scriptures differently from the religious leaders of his time, being the Pharisees and Sadducees. He gathered quite a few followers around him and started to teach them - they became the first believers in Christ's teachings. After his resurrection and ascension, Jesus' followers became a separate group in Jerusalem. The city (being the main centre of Judaism) thus also became the main centre of the believers in Christ's teachings after the ascension of Jesus.

The origin of Christianity in its infancy was therefore definitely linked to the Judaism of Jerusalem, especially through the Jewishness of Christ and the shared Scriptures of both religions (Fogarty 2004:6). This new belief system or religion, therefore, mainly consisted of Jews who belonged to Judaism, but who broke away from Judaism because of their belief in Christ and his teachings. The new religion developed alongside Judaism in Jerusalem. In many religious respects, the followers of this religion at first still joined Judaism, visiting the Temple or synagogues every Sabbath and keeping the Jewish Laws such as circumcision, et cetera. At first, the new religion was therefore not really distinguishable from Judaism. Even, as is later stated, when they began to reject Temple worship and developed their own view of the Torah, there was still no definite distinction between the two groups. Maybe Jerusalem was too Jewish for them to really start a wholly separate religion there?

Jesus was the main determinant for the foundation of the 'new' religion. Although it was not Jesus' intent to start a new religion (cf. Frend 1992:38), scholars may argue that his articulation in Matthew 16:18 ('And I tell you that you are Peter, and on this rock I will build my church, and the gates of Hades will not overcome it' - New International Version [NIV], author's own emphasis) was a clear indication of his intent. However, the Gospels did not record an event or place where Jesus founded a new church. The phrase 'on this rock' referred to Peter's confession in verse 16, 'You are the 
Messiah, the Son of the living God', whilst 'I will build my church' could be a referral to a future event.

Jesus was not the Messiah that the Jews expected on the grounds of their interpretation of their Scriptures. Their interpretation led them to expect a political Messiah (cf. Is 9:6; cf. also the New Testament passage of Mk 10:37). Jesus explained to his disciples that they misunderstood the intention of God: God sent his Son to earth to die for the salvation of mankind (Jn 3:16) and not to be a political leader (cf. Mt 16:21 where Jesus referred to his passion). It is important to state that, in this passage, Jesus used the forms and content of biblical Jewish experiential wisdom (Georgi 1995:42). As Judaism did not acknowledge Jesus as the true Messiah, they are still awaiting the arrival of their Messiah to this very day.

After the ascension of Jesus, the believers in Christ's teachings in Jerusalem first had Peter as leader and after his departure for Rome, James, Jesus' brother, succeeded him (cf. also Josephus Ant. 20.200). They were still practicing, circumcised Jews, who at first remained Temple-centred and traditioncentred and were observers of the Jewish Law. Although they were a distinct group, they did not have a distinctive religion (cf. Goldenberg 2002:586-588).

After the Jewish War of 66-70 CE, which included the fall of Jerusalem and the Roman destruction of the Temple in $70 \mathrm{CE}$, many Jews (i.e. orthodox Jews as well as believers in Christ's teachings) fled Jerusalem for places such as Transjordan, Syria and Alexandria, and the Jewish state no longer existed (Fogarty 2004:47, 104). One group of Jews, however, remained in Jerusalem until the Second Revolt in 132-135 CE (Fogarty 2004:105-106).

Toward the end of the 21st century, the most important feature found in Jerusalem was the consolidation of Pharisaic Judaism, leading to the so-called Birkath-ha-Minim, which effectively excommunicated the believers in Christ's teachings from the synagogues in 85 CE (Frend 1983:53; Pearson 1986:213-214).

\section{The 'first signs' of a split between Christianity and Judaism: Biblical evidence}

In this section, the antagonism between Jesus and biblical authors, on the one hand, and the Jews and Judaism, on the other, is pointed out by referring to a few polemical quotations from the New Testament. These quotations are taken from different parts of the New Testament, leaving the impression that the mentioned Scriptures are uncritically harmonised. It is, however, not the intention of this article to discuss the Synoptic Problem, authorship of the Pauline Epistles, et cetera, but to cite quotations made by biblical authors indicating that Jesus did not live in harmony with the religious leaders of his time. These serve as indicators that a separation between Judaism and the believers in Christ's teachings already had its origins in Jesus' time. One must also take into account that these Scriptures were written much later at different places and with different points of view:
- In Matthew 23:13-36, Jesus spoke out against the Pharisees and scribes with words such as 'hypocrites', 'blind men', 'blind fools', 'serpents' and 'brood of vipers'.

- In Mark 11:17, Jesus accused the Jewish leaders of making the Temple a den of robbers.

- In Mark 13:2, Jesus prophesied that 'this Temple' (referring to his body) would be demolished.

- Jesus also corrected the Law of the Jews and they despised him for that (cf. Jn 8:1-11).

- In Acts 7:51, Stephen indicated to the Jews that they were resisting the Holy Spirit and that their circumcision was not really an act of faith.

- In Romans 2:17-19, Paul accused the Jews of relying more on the Law than on God: the Law, and not their faith in God, made them guides to the blind. A few verses later, in verse 23, Paul's accusations reached a pinnacle when he said that the Name of God is blasphemed by the Gentiles, because the Jews were constantly breaking the Law.

- In Romans 10:4, Paul told the Jews that Christ is actually the 'end of the Law' - this was blasphemy in the eyes of the Jews.

- In Philippians 2:9-11, Paul made another 'blasphemous statement' by saying that Jesus' Name was the Name above all names. The Jews considered Jesus as only a human being, who also died by execution, which was highly impure (Georgi 1995:44). This was an absolute offense to Jewish faith, as they held the Name of God to be the most high.

- In John 8:44, Jesus told the Jews that their real father was the devil. In Revelation 2:9, the author refers to the Jewish synagogue as a synagogue of satan.

- All these articulations about the Jews and Judaism can be seen in the conclusion of Paul in Acts 13:46 (free translation): 'It was necessary that the Word of God should be proclaimed first to you. Since you are not interested in it, you judge yourselves unworthy of eternal life; therefore we shall now turn to the Gentiles.'

- During the time of Jesus, it was common practice to baptise a person on entering into a new religion. The Jews who converted to become followers of Christ also had to be baptised as a token that their 'sins' (of the previous religion) were forgiven (Ac 2:37-38, 41). The fact that there were two groups (the baptised and the unbaptised) led Paul to start referring to the followers of Christ as 'us' opposed to the Jews (2 Cor 3:17-18) and to conclude that a follower of Christ has made a new beginning and therefore was a new person and creation (2 Cor 5:17).

- In Acts 11:26, it is reported that the followers of Jesus were called Christians in Antioch, clearly distinguishing them from the Jews.

- Although Jesus was a Jew, the Gospels indicated in many instances that the Jews turned away from him, culminating in his death on the cross - 'Crucify him!' (cf. Mt 27:22-23).

- In Acts 2:10, it is recorded that Jews from Egypt attended Peter's Pentecost speech. In Acts 6:9, Jews from Cyrene and Alexandria were present at the controversy with Stephen, the first Christian martyr. In Acts 18:24-25, the author mentioned Apollos who was a learned Jew from 
Alexandria, well educated in Scriptures, and most likely to be a believer in Christ's teachings. This refers to the middle of the 1st century CE!

- Acts 18 is an indication that there had to be missionaries in Alexandria during the first half of the 1st century CE. Pearson (1986) stated:

... there can hardly be any question that the earliest missionaries to Alexandria were Jews coming from Jerusalem, and that the earliest Christian converts in Alexandria were Jews. Indeed it is doubtful that a clear separation between church and synagogue was effected there until the end of the 1 st century or the beginning of the second. (p. 210)

\section{'Parting of the ways' or becoming a distinctive religion?}

It serves to mention that there is a slight difference in the meaning of the two phrases 'parting of the ways' (interpreted as separation) between Christianity and Judaism, as referred to in Becker (2003), and Christianity becoming a distinctive (distinguishable) religion. 'Parting of the ways' only indicates that the two forms of the one religion had 'split up', whilst a distinctive religion indicates two distinguishable religions.

Becker (2003) alluded to the parting between Christianity and Judaism as follows:

There were, in fact, many 'partings', and they happened in different places at different times in different ways; furthermore, the Jewish and Christian communities continued to be intertwined in certain ways at certain times. (p. 392)

Cohen (2006:224-225), on the other hand, referred to the separation of Christianity from Judaism as a process, not a once-off event. The essential part of this process was that the church was becoming increasingly gentile and less Jewish. This process would end in $70 \mathrm{CE}$, after the great revolt, when various Jewish sects disappeared and Pharisaic Judaism evolved into Rabbinic Judaism, whilst Christianity emerged as a separate religion. Only two organised groups (of this one religion) then remained, namely the Early Christians and the Pharisees.

Christianity in its earliest forms (originating in Jerusalem and coupled with Judaism there) reached Africa, especially Egypt, and found it very receptive to the Good News. Pearson (1986:221) stated that Christianity in Alexandria was more reflective of the Jerusalem origins of the Christian mission, as well as the dominant varieties of Judaism in the city at that time. Fogarty (2004), however, had the view that, although the beginning of Christianity in Alexandria was:

inexorably linked to Judaism through the Jewishness of Christ, and the shared Scriptures, the development of Christianity had little to do with Judaism per se and everything to do with the Hellenic world, in the first place, and the Roman world in the second. (p. 6)

Fogarty's opinion was actually derived from Adolf von Harnack (1915), who had the view that Christianity actually replaced Judaism after the destruction of the Temple in Jerusalem:
The Jewish people, by their rejection of Jesus, disowned their calling and administered the death-blow to themselves; in their place came the new people of the Christians, who took over the entire tradition of Judaism. (pp. 70-71)

Von Harnack acted as a 'major proponent' of the old view held by scholars roughly a century ago (cf. Jacobs 2003:97-98). As opposed to this 'old view', Becker's (2003) point of view seems more acceptable when applied to the earliest Christians in Alexandria. There was no clear distinction before $117 \mathrm{CE}$, but after that Christianity became distinctive from Judaism.

\section{Christianity outside Jerusalem - Antioch}

The first group of believers in Christ's teachings to leave Jerusalem for Antioch (Pearson 1997:17 called them 'trajectories') was banished because of their rejection of Temple worship and their views concerning the Torah, as reported in Acts 6:1-8:4 (Fogarty 2004:105). This first 'trajectory' was led by Stephen and other 'Hellenist' leaders (Jews and converted Greeks) in Jerusalem. Antioch later became an important centre for the development of early Christianity, with Paul's formation of a doctrine (a law-free gospel for the Gentiles - cf. Reed 2003:189) taking place there. Pearson (1997) elaborated on the 'trajectories':

We can thus trace a 'trajectory' that leads from a Greek-speaking group of Jewish believers in Jesus in Jerusalem (Acts 6-8) to a Greek-speaking group of Jewish and gentile believers in Antioch who are given the name 'Christian' by outsiders (Acts 11); to a gentile mission led first from Antioch by Barnabas and Paul (Acts 13-14); to the independent activity of the apostle Paul, resulting in a network of churches influenced by Paul's teachings (Acts 15-28 plus the Corpus Paulinum); to Bishop Ignatius of Antioch, who embraced Christianismos as a religion distinct from Judaism and who also provides us with the first instance of the term 'the catholic church' (Smyrn. 8.2). (p. 17)

In the new religion, different leaders, be they charismatic like Paul, or scholarly like Ignatius of Antioch, were developing interpretations of Christ's teachings as they went along. During the 1st century there was no systematic doctrine for Christianity. The belief system differed from group to group. In Jerusalem the 'Ebionites', a strictly Jewish Christian group, followed the Petrine or Johannine line, whilst in Antioch especially Paul, and later Ignatius, developed a far more dogmatic line, which (with special reference to Paul) became Western Christianity's theological basis henceforth.

By the end of the 1st century and during the 2nd century, Christianity began to evolve into a religion, with commentaries (theologies) written by Ignatius of Antioch, Irenaeus of Lyons and Clement of Alexandria. Other 1stcentury and 2nd-century writers were Clement of Rome, Polycarp of Smyrna and Theophilus of Antioch, who also had an influence on the Early Church. The Synoptic Gospels were editorialised narratives, whilst John's Gospel was a mystic-Gnostic writing. The product of these 2nd-century developments and beyond was a discursive treatment of Christian issues, in dialogue with the world around them 
and, more specifically, with the religions of Judaism and Gnosticism (Fogarty 2004:103).

In Antioch, Paul's Greek letters (1st century) and Ignatius' affirmations thereof (2nd century) started the separation between Judaism and the Christians there (cf. Fogarty 2004:108). Ignatius of Antioch (35[50] - 98[117] CE) regarded Christianity as distinct in Antioch (cf. Robinson 2009:204ff.). His view was that there existed one Judaism and one Christianity and that the boundaries between Jews and Christians were significant and clear. This could be true for Antioch, but it was not true for Alexandria.

\section{Why Alexandria?}

In this section, the notion will be discussed as to why Alexandria is regarded as the place where the Christian religion best found and made its own stand during the formative years of Christianity.

\section{Background to Alexandria}

When he created a new Egyptian capital (later called Alexandria) out of the harbour village of Rhakotis in 331 BCE (cf. Isichei 1995:13), one of the wisest approaches of Alexander the Great was religious tolerance, whereby he permitted the indigenous religion of Egypt to remain intact alongside the Greeks, with their numerous gods, and the Jews. After Alexander's death, a war of succession followed between 321 and $306 \mathrm{BCE}$, ending in the formation of three kingdoms: the Macedonian Empire, the Seleucid Empire, based in Syria and Mesopotamia, and the Empire of the Ptolemies, based in Egypt and Cyrenaica (Fogarty 2004:14). The Ptolemies perpetuated the policy of Alexander (Fogarty 2004:6).

According to the Coptic Orthodox Church Network (n.d.), long before the establishment of Christianity in Alexandria, the city was already famous for its many schools, signifying that this city was an 'arsenal of knowledge'. The most significant school was the Museum (shrine of the Muses), founded by Ptolemy and well known in the East. The two other schools worth mentioning are the Serapeum and the Sebastion. These schools each had their own vast libraries. The Museum's library, for instance, housed 700000 volumes, which was astounding for its time. These institutions made Alexandria famous as a centre of knowledge.

In $30 \mathrm{BCE}$, Egypt became part of the Roman Empire after the suicide of Cleopatra, who was the last of the Ptolemies. However, the language of the city and of scholarship did not change to Latin, but remained Greek, whilst Egyptian (called Coptic) was the 'language of the countryside' (Isichei 1995:13).

Beside the fact that Alexandria was geographically well positioned, the city produced intellectual work most desirable for the ancient Greeks and also for the Jews. A considerable numbers of exiled Jews settled in Alexandria, thus further enriching the city's life through their scholars, merchants and skilled artisans (Fogarty 2004:6). Many of them were believers in Christ's teachings. The religious life of Palestine therefore came into contact with the intellectual culture of Greece. According to Enslin (1954:214), there were more Jews in greater Alexandria than in all of Palestine. The Coptic Orthodox Church Network (n.d.) stated that there were numerous Jewish schools scattered everywhere in the city. Apart from the Jews (with their Scriptures), there were also Babylonians (with their astrology), Persians (with their dualism) and a mass of other religions.

Alexandria grew into a cosmopolitan city and was chosen by many as a home for learning: Egyptian, Greek and Jewish cultures (belonging to Judaism, as well as the believers in Christ's teachings) mingled with eastern mystic thoughts to develop a new civilisation. For the next few centuries, Alexandria stood out as one of the three leading cities of the ancient world (Oden 2007:17-18). At its zenith, this AfroHellenic city had grown larger than Rome and Antioch and became far more important in the world of ideas, literature and learning than these two cities. Here the religious life of Palestine commingled with the intellectual culture of Greece, preparing the way for the first school of theology called the Catechetical School of Alexandria, aiming at a 'philosophic comprehension and vindication of the truths of revelation' (Schaff, in Coptic Orthodox Church Network n.d.). Enslin (1954) strikingly compared Alexandria to Rome and Athens as follows:

... at the time of the early spread of the ferment subsequently to be known as Christianity this city, with its museum, its unmatched libraries, its host of scholars in all the fields of human thought, not simply tolerated by the civil authorities but sought after and given every encouragement and support, was the unrivalled intellectual centre of the Roman world. It had snatched the torch from the fingers of 'violet crowned, illustrious Athens', long the undisputed centre of learning but now but a shadow of her former self ... Rome with its genius for organization and administration was no rival. (pp. 213-214)

Fogarty (2004:33) claimed that Christianity (qua Christianity) had its origins in Egypt, and in Alexandria in particular.

\section{The development of Christianity in Alexandria}

Apart from the group of 'Hellenists' who left Jerusalem for Antioch (cf. the section entitled 'Christianity outside Jerusalem - Antioch' above), another group moved to Alexandria soon after Stephen was stoned to death (Fogarty 2004:106). Their flight from Jerusalem formed the first and very important step in separating them from the Judaism in Jerusalem, as they took their beliefs with them into the secularist Hellenised world. During their first years in Alexandria, the development of Christianity happened alongside, but not totally separate from, the newly formed Judaism in the city. The time was right for this group of believers in Christ's teachings to act as missionaries amongst the Jews who already lived there and who did not have a big preference for the Temple and other ritual observations, 
rather favouring a spiritual interpretation of their tradition (Pearson 1986:213). Pearson (1986) described it as follows:

It need hardly be stated that the first preaching of the gospel of Messiah Jesus in Alexandria was centered in the Jewish community there, the largest and most powerful Jewish settlement in the entire Greek-speaking world. (p. 207)

The believers in Christ's teachings had to find a place to live and settle in Alexandria whilst disseminating their religious beliefs. They initially gathered in what can be called 'housechurches' (Coptic Orthodox Church Network n.d.).

Alexandria must have kept more to the Jerusalem tradition (already mentioned), because of the visits of Mark the Evangelist during the middle of the 1st century (after $40 \mathrm{CE}$ ). This would eventually develop into what became known as Coptic (Egyptian) Christianity (Fogarty 2004:6, 107). The fact that there was such a mixture between Jewish beliefs and the new belief in Jesus, made it possible for the early followers of Jesus to adhere to Judaism as well as the teachings of Jesus - especially for the 1st century and the beginning of the 2nd century CE in Alexandria.

This city was one of the most fertile areas for the development of the early Christian movement, because of its unique location in the intellectual centre of the ancient world. But as Christianity in its infancy began to take root in Alexandria, it was surrounded by the influences of intellectual Hellenism, as well as the Egyptian religion, rituals and iconography. It could also not have escaped a certain amount of influence from the older, surrounding religions and philosophies. Many elements of the local religions influenced the rituals and formations of the new religion and are traced through ancient Egyptian religion, the Isis and Serapis cults, Gnosticism and Hermeticism (Fogarty 2004:8). From the start, therefore, these believers were influenced by all the cults and philosophies in the city that formed part of the Hellenic culture and Roman power present in Alexandria. Walter Bauer (1971:44-60) had the view that the original and most dominant form of Christianity in Alexandria until the time of Bishop Demetrius (189-231 CE) was 'heretical' and, specifically, Gnostic, as Gnostic teachers such as Basilides, Valentinus and Carpocrates were active in the city.

Alongside the new Christian movement, Judaism also developed and established itself in Alexandria (cf. Boyarin 2003:65). Interestingly, the Jews enjoyed more civil rights here than the Egyptians (Fogarty 2004:48). Judaism in Alexandria was, however, very much divided. At least two groups can be pointed out, the one being educated, cultured Jews who were in favour of a synthesis between Judaism and Hellenism, of which Philo was part, and a 'lower' group that championed messianism and had a fighting spirit (Tcherikover 1963:22-27). Although a Jewish Gnosticism arose in Alexandria, Judaism remained implacably separate from them, a situation perhaps assisted by the Ptolemies' protection and, later, by the Romans' as well, in contrast to the way the Romans treated them in Jerusalem.
But then the Jews belonging to Judaism in Alexandria decided to revolt and this led to the separation of the 'new religion' from Judaism. Van den Hoek (1997) articulated it as follows:

Some scholars have argued that Alexandrian Christianity came out of Judaism and that this Jewish background remained a major influence. This may have been true before the Jewish revolt (115117) and its suppression by Trajan. By the late second century, however, events had radically attenuated that continuity. In all likelihood, Clement and Origen's link with Philo and other Jewish Hellenistic or Jewish Christian sources was primarily a literary one. Clement does not reflect living contacts with Jewish scholars, although Origen does to some extent, particularly in his later years in Caesarea. Even Christian authors of the time of Hadrian and the Antonines [Antoninus Pius 138-161, and his son Marcus Aurelius 161-180] reveal no clear signs of a relationship with a Jewish or Jewish Christian ambience. Whatever happened around the time of Hadrian, the traditional watershed in Jewish and Christian Alexandria, the living contacts with Judaism seem to have vanished thereafter. (pp. 80-81)

Pearson (1986) also referred to the revolt by saying that:

the political situation in Alexandria reached a critical point when the messianist Jews there sparked the revolt against Rome under Trajan (115-117) that led to the virtual annihilation of the Jewish community. (p. 214)

Although almost nothing was mentioned about the role the Christians played in that conflict, it looks likely that, after the revolt, the 'parting of the ways' then developed into a distinctiveness for both groups and their views, especially for the Christians. This process started in 117 CE (cf. Frend 1992:46) and was more visible in 138 - the death of Hadrian. Alexandria, as the intellectual matrix of the Graeco-Roman world, therefore became the key centre of the Roman Empire in which the new religion was formally developed (cf. Fogarty 2004:abstract). This city, being the metropolis of Egypt at that time, became one of the great centres of Christianity (more important than Antioch and Rome).

\section{The Didaskaleion}

During the first half of the 2nd century, most of the believers in Christ's teachings living in Alexandria were Jews. By the middle of that century, as a result of missionary work conducted by the believers, things changed considerably: the new religion in the Delta city developed and grew in numbers, resulting in the Didaskaleion - a Catechetical School being established in opposition to the pagan philosophical schools. Although the view of scholars such as Scholten (1995) and Van den Hoek (1997) was that the School was limited to the initiation of catechumens and (maybe) the teaching of theological subjects, whilst Science, Mathematics, Greek and Roman literature, Logic and Arts were also taught there (cf. Hist. Eccl. 6.18.3). According to the New World Encyclopedia (2012:n.p.), 'the question-and-answer method of commentary began there, and fifteen centuries before Braille, woodcarving techniques were in use there by blind scholars to read and write'. The School was advertised abroad and attracted large numbers of students from the Mediterranean World. One of the determinant reasons was that Alexandria was 
a world famous city, especially renowned for its academic excellence as mentioned above. The heads of the School were Greek-trained, therefore putting the educational principles of the School firmly in Hellenism. All the students at the School were trained in Greek philosophy, thus gradually departing from the Jewish customs in which the early believers would have engaged (Fogarty 2004:29).

According to Eusebius (Hist. Eccl. 2.16) and Jerome (who was one of the later attendees of the School), Mark the Evangelist founded the School in the early 40s CE. The Didaskaleion became the oldest centre for sacred sciences in the history of Christianity. This School was the first to develop a system of Christian theology, as well as the allegorical method of Biblical exegesis, a 'style of interpretation long associated with the delta of the Nile ... It is to be found on every page of his [Clement's] writing and is fantastic in the extreme' (Enslin 1954:238). As the founding of the School by Mark is disputable, the two most prominent (undisputable) figures who were heads of the School were Clement and Origen. With regard to all the scholars at that time, Fogarty (2004:131; cf. Barnard 1964:145-150) stated that none of the early scholars in other centres in the Roman Empire could equal the prolific output and brilliance of argument, embedded in the sophistication of the theology formulated by Clement and Origen. Through the outreach of the Catechetical School in Alexandria the Egyptian Christianity made its mark in the world.

\section{Clement (159-215 CE)}

Clement was one of the pagans attending the Didaskaleion. He was born in Athens to a pagan family during the reign of Emperor Antonius Pius (Roberts \& Donaldson 2004:166), with Polycarp still living, and with Justin and Irenaeus in their prime. Before he went to Alexandria, he first studied under Christian teachers in Greece, Magna Graecia, Syria and Palestine (Van den Broek 1995:42).

Under the influence of Pantaenus, who allegedly also was a head of the School, he became a Christian and one of the great teachers at the School. He headed the School from 193-202 CE. Little is known of his life, except from what we learn from his writings and what others witnessed about him. Origen remarked in one of his major works, Contra Celsum 1.48, that Clement 'at all times avoided unnecessary talk about himself'.

The Early Church could not offer a better example of an intellectual Christian than Clement. He insisted that the goal of Christian education was 'practical, not theoretical and its aim is to improve the soul, not to teach, and to train it up to a virtuous, not an intellectual, life' (Paed. 1.1.1.4-2.1). Owing to the philosophical background of Clement, Schaff (1910:782) called him the father of the Christian philosophy in Alexandria and also declared Clement the founder of formalised Christianity (Schaff 1855b:696). According to MacCulloch (2009:148), Clement was one of the earliest
Christian writers on moral theology, because of his detailed address on a Christian's daily life, focused on moral progress.

Clement was so impressed by the interpretative work performed on the Scriptures by Philo that, in his own biblical commentaries, he adopted Philo's method of interpretation to construct a specifically Christian understanding of the Scriptures (Fogarty 2004:126). He made use of the available knowledge of the time in rebutting the pagan beliefs as well as the heretical views of some Christian groups. This was in contradiction, to some extent, to Tertullian with his baser swiping method and Irenaeus, whose writings were sometimes rather more florid and fanciful opinions (cf. Fogarty 2004:126). Clement was responsible for the initiation of a Christian theology through his scholarly works. His legacy spread even further (cf. Fogarty 2004:127):

- His insistence on a spiritual life based on self-discipline and gospel values laid the foundation for monastic living which was to develop in the future decades.

- He appealed to Christians to become well educated in order to be better witnesses to both believers and nonbelievers.

- He believed further education was also the path to salvation and therefore real gnosis.

This renowned writer reserved biblical interpretation for the Christian intellectual, purely out of concern for misunderstanding and not to constitute an 'elitist theology' as Gonzalez (1984:73) claimed. This attribute would belong to Clement's student, Origen.

Clement's writings include his famous Trilogy, the Protrepticus (c. 195), the Paedagogus (c. 198) and the Stromateis (198-203). These three writings are 'among the most valuable remains of Christian antiquity, and the largest that belong to that early period' (Schaff 1885a:372). He was also the author of Quiz dives Salvetur? - a very practical treatise showing the reader that the attitude of the soul is of greatest essence - and many other writings.

Clement was the first theologian who started to focus on central problems of Christian theology, like how to reconcile faith with knowledge, as well as how to utilise secular learning in order to elucidate the revelation given in biblical texts. He worked with his texts in an exuberant and optimistic way which encouraged many theologians through the ages. One of his favourite texts was, 'Seek and you shall find' (Mt 7:7) (cf. Kovacs 2009:270).

Clement's brilliance and comprehensiveness in his works lay a vital, sophisticated foundation for the development of Christian theology and was a key reason for the ongoing development of theological work carried out by his successors at the Catechetical School (until its demise in the 5th century). According to Kovacs (2009:262), his writings were the earliest surviving works denoting a connection with Alexandrian Christianity. After his death he was 'held in high esteem by those who took up the task of Christian theological exploration' (Kovacs 2009:269). 


\section{Origen (185-253[4] CE)}

Origen, born in Alexandria to Christian parents (Hillerbrand 2012:41), was appointed head of the Didaskaleion in 203 by Bishop Demitrius. He was perhaps the most famous student of Clement and it appears that the School reached its zenith under him. Taking up the position as head of the School at the very young age of 18 years (Hist. Eccl. 6.3.3, 6.15.1; cf also Hist. Eccl. 14.11, 26.1), he grew as theologian to become 'the father of theology' (Coptic Orthodox Church Network n.d.) or as Vrettos (2001:181) put it, 'the father of theological science', as 'he created a solid system of dogma and laid foundations for scientific criticism of the Old and New Testaments'. He was the first theologian to 'offer a systematic understanding of the Hebrew Scriptures as the Christian "Old Testament"' (Hillerbrand 2012:43).

As a systematic theologian, he would first lay out the basics as well as the details of the Christian faith coherently and systematically, in order for his readers to understand the notions he wanted to advance. Being a systematic theologian, he was reflective and thoughtful in his writings. His goal was to search for a deeper meaning - a higher truth in Scripture. He therefore discouraged dependency on the literal meaning of a text. Truth in Scripture should not be read as linear historical events, but as myth - offering a deeper explanation of truth (cf. MacCulloch 2009:112). 'By introducing historicity into the conversation on allegory and biblical interpretation, Origen is credited as the initiator of historical philosophy' (McLelland 1976:117).

Origen was a master of allegory, as he was convinced that Scripture has several layers of meaning. He used this method because he regarded literal interpretation of the Bible as a stumbling block for the educated pagans (Barrett 2011:53). He combined the allegorical method of interpretation with logical consequences of Scriptural inspiration, thus developing a threefold sense of Scripture, namely a grammatico-historical, a moral, and a pneumatic sense - the latter one being the most significant level of meaning. His way of using this method influenced - rather dominated - Christian biblical exegesis until the 16th century with the Protestant Reformation (cf. Hillerbrand 2012:43). This contributed to the School's idea to be an intellectual expression and a philosophical basis for Christianity. His doctrine of God is one of the best developed doctrines in the history of theology (Barrett 2011:52).

His view was that biblical interpretation was open for misunderstanding and therefore he preferred to reserve it only for the spiritual elite - evoking a sort of Christian elitism (Barrett 2011:53). This was fostered by the School, only as an attempt to preserve the integrity of biblical meaning. This action would flow over in teaching the true meaning to those who are limited to a literal understanding. The influence of this elitism flowed over to the Reformation (McGrath 2007:2).

Lynch (2010:98) considered Origen as the first critic of the Bible who attempted to 'systematically organise the Old Testament'. After mastering Hebrew, Origen started to work on his Hexapla. With this he provided a method of textual comparison of the Old Testament. Origen also contributed on the level of typology with which he compared the Old and New Testaments with each other. At that stage the canon of the New Testament was not yet set. He already accepted the four Gospels as authoritative. The struggle Christians had at that time was to reconcile the Old Testament with the new covenant presented in the New Testament. Origen utilised typology to interpret both, understanding the elements of the Old Testament as a foreshadowing for what was to come in the New Testament. 'Typology was the same method which explained allegorical interpretation; the literal meaning of scripture was confronted by the deeper, and more elusive, figurative meaning' (Barrett 2011:54-55).

Origen's writings were 'the first attempt at a system of Christian doctrine, or philosophy of the Christian faith; a pivotal moment in the development of Christian thought' (Barrett 2011:40; also cf. Harris 1966:42). In addition to his famous Hexapla, he wrote more than 6000 commentaries on the Bible.

\section{The development of a Christian theology in Alexandria}

Whilst Jerusalem was the origin of the new religion, Christianity found its feet in big centres of the Roman Empire such as Rome, Antioch and Alexandria, and in a more academic way in the latter city, having founded a Didaskaleion there. The other two cities also boasted schools, but not on the level of the Didaskaleion (Burton 2007:119; Groves 1948:36-37). Alexandria, developing into a world famous city and renowned for her academic excellence, was therefore the only of these three cities to establish a theological 'university' for students, especially during the times of Clement and Origen. This paved the way for the development and formation of a first Christian theology in Alexandria. Together with Carthage (especially with Tertullian and Cyprian), Africa became the bastion for Christian theology (cf. Oden 2007:98).

The Didaskaleion in Alexandria, therefore, became the oldest centre for sacred sciences in the history of Christianity and was the first to develop a system of Christian theology. Alexandria can be constituted for the formation of the Christianity which was to reach the whole world, as Baur (1994:22) put it: 'So it is understandable that Christian theology in the proper sense of the word first started in Alexandria.' Baur used the word 'theology' to indicate that it was not merely a superficial religion, but this religion had already started with its own theology on an academic level.

Alexandria became the intellectual capital of Africa, with Christianity well established in it, well before Europe could produce such a centre. Only after this 'rich wisdom' had been 'cradled and nurtured and schooled' did Africa offer its rich wisdom to the cultures of the northern side of the Mediterranean (Oden 2007:94). Oden (2007) used the metaphor of a plant that blossoms to describe the development of Christianity in Africa: 
African intellectual history represents the first major blossoming of the Christian mind. The blossom would not occur without the plant. It occurs in its own time and place - Africa. If a slowgrowing plant has a spectacular blossom, at that moment it displays the beauty of the whole organism, which is ecumenical Christianity. The blossom is African intellectual brilliance. The blossom cannot be detached from its roots, for then it dies. Its roots are the apostolic witnesses in Africa. Without the previous stages of preparation of the nations and the covenant people, there would be no blossom. The timing of plant growth within its ecosystem must be respected. It would be absurd to curse a beautiful blossom merely because it was slow in growing. That would say more about the dismissive party than about the plant. To detach Egyptian and Numidian Christianity from Africa is to detach the blossoming of the early Christian mind from its context. (p. 94)

\section{Two relevant matters The rise of the Coptic Church}

Despite the older, entrenched religions in Alexandria, Christianity began to arouse interest amongst Greekspeaking peoples in the city and was later to become the religion of choice amongst native Egyptian people, to such an extent that it eventually became the national religion of Egypt (Pearson 1997:xvii). This position was upheld until the Arabs conquered Egypt in the 7th century CE.

Whilst an Egyptian Christianity initially made its mark in the Empire (through the outreach of the Catechetical School in Alexandria), it was indubitably the unique qualities of the Hellenistic world that made the spread and reception of the religion possible and such an attractive proposition (Fogarty 2004:131). The remnants of those earliest Christians are to be found in their descendants, the Copts, who form some $10 \%$ of the population of Egypt today. Oden (2007) put it this way:

The central confessions and liturgies and prayers and Scriptures of the Coptic tradition were once closely shared with both the Byzantine and Latin traditions of Africa, by both the ancient sees of Alexandria and Carthage. This ecumenical core has never been entirely absent in Africa during the last twenty centuries. This core is largely identical with early consensual African Christianity. It has remained intact in global Christianity and now is gradually reawakening in Africa with full vitality. (p. 98)

\section{'Going home'}

Sometime between the 21st and the 19th centuries BCE, God called Abraham to be the founder and father of his Chosen People (Gn 12:1ff.). Terah, the father of Abraham, lived in $\mathrm{Ur}$ in Babylonia (the land of the Chaldeans), but decided to move from there to the north-west and settled in a city called Harran (Haran) (cf. Gn 11:31). There Terah died and there God called Abraham when he was 75 years old. Abraham and his family (including his wife and his nephew Loth and his family) then moved in a south-westerly direction to the land of Canaan. There they settled in Shechem, a holy place of the land. The Chaldeans formed part of Mesopotamia, together with the Sumerians, Akkadians, Amorites, Babylonians, Assyrians and Aramaeans. Their language was and still is Aramaic (Shathaya 1999).
A biological study conducted by Clyde Winters (2010:296, 298) proved that about 5000 years ago there was a migration of Kushites (from Africa) to Eurasia. Linguistics and DNA studies proved that Abraham's ancestors were part of the Kushites who migrated from East Africa to Asia (Linsley 2010). Abraham's ancestors more specifically moved from the Upper Nile Valley and the Horn of Africa to the coastal areas of Arabia. There they established themselves in separate territories. The name of Terah (Abraham's father) was associated with the Nilotic Ainu, originating from the Upper Nile Valley. The Ainu migrated from East Africa eastward, as far as Japan and north to Southern Siberia (Linsley 2010). These rather astounding facts link Africa even closer to the Jews and therefore to Christianity. In fact, the believers in Christ's teachings who migrated to Alexandria were actually just moving back to the land from which their ancestors had come.

\section{Conclusion}

Concerning the primary sources for the Early Church, two restrictions are outstanding:

- The sources for the Early Church in Africa at our disposal are limited especially regarding 'actual facts'. One of our main sources is the most famous work of Eusebius of Caesarea (Palestine) called Historia Ecclesiastica, which he wrote during the reign of Constantine in 306-337 CE, but time and again he is 'proved' to be wrong by modern scholars and sometimes with good reason.

- Fortunately, scholars such as Clement and Origen wrote many manuscripts, but very little of them is extant.

These two restrictions complicate the study of this era to a large extent. Added to this, some modern scholars, such as Darkwah (2005) and Oden (2007), can be criticised as being very positivistic about Africa, whilst others may be seen as too critical, such as Scholten (1995) and Van den Broek $(1995,1996)$. With all these in mind, it boils down to the interpretation of facts versus 'facts'.

In short, it can be stated that after the ascension of Jesus Christ (c. 30 or $32 \mathrm{CE}$ ) quite a few events took place concerning the development of the new religion later called Christianity:

- There was antagonism of Judaism towards this new sect, which led to Peter fleeing Jerusalem (and Paul being somewhat scared to visit Jerusalem).

- The destruction of the Second Temple (70 CE).

- Jews (belonging to Judaism in Jerusalem) and believers of Christ's teachings left Jerusalem and found refuge outside Palestine in places such as Rome, Antioch and Alexandria.

- In each of these cities, these two groups had to settle themselves anew, although there could have been members of their groups living there already.

- In each of these cities, the two groups became distinct from each other at a certain point: in Antioch it seemed to have happened by the end of the 1st century, whilst it most probably happened in Alexandria during the first half of the 2 nd century CE. 
- Finally, there was the Bar Kochba Revolt from 132-135 CE where all Jews in Jerusalem were banned from the city.

As Alexandria was the academic centre of the Roman Empire, with schools such as the Museum, the Serapeum and the Sebastion, the Didaskaleion was established by the believers in Christ's teachings living in this city as a Catechetical School to oppose the pagan philosophical schools. Amongst others, the two most important heads of the School were Clement and Origen.

In this article, Clement was attributed with the following characteristics:

- an intellectual Christian

- the father of the Christian philosophy in Alexandria

- the founder of formalised Christianity

- one of the earliest Christian writers on moral theology

- a 'better' theologian than Tertullian and Irenaeus

- the initiator of a Christian theology through his scholarly works

- creating brilliant and comprehensive works which laid a vital foundation for the (further) development of Christian theology.

Origen was attributed with the following characteristics:

- the father of theology and theological science

- producing one of the best developed doctrines of God in the history of theology

- the initiator of historical philosophy

- a master of allegory

- the first critic of the Bible who attempted systematically to organise the Old Testament

- producing writings that were the first attempt at a system of Christian doctrine, or philosophy of the Christian faith; a pivotal moment in the development of Christian thought.

All these facts allow us to conclude that Alexandria played a major role in the formation of a Christian theology during the time of the Early Church and was probably the most important root for the theology of Christianity, therefore:

It should not be surprising that the Christian leaders of Alexandria came to symbolize and represent all Christians on the continent in terms of ecclesiastical organization ... Many Christian ideas and practices travelled north to Europe from the Nilotic and Numidian cultures. Nilotic and Numidian cultures are the epicenter for the pre-European history of Christianity. (Oden 2007:17-18)

\section{Acknowledgements Competing interests}

The authors declare that they have no financial or personal relationships that may have inappropriately influenced them in writing this article.

\section{Authors' contributions}

W.H.O. (University of South Africa) was the mentee who did all the research and wrote the article. M.J.S.M. (University of South Africa) was the mentor giving advice and helping on request.

\section{References}

Abrams, M.H., 1993, A glossary of literary terms, 6th edn., Harcourt Brace Jovanovich College Publishers, Fort Worth.

Barnard, LW., 1964, 'St. Mark \& Alexandria', Harvard Theological Review 57(2), 145150. http://dx.doi.org/10.1017/S0017816000005460

Barnard, L.W., 1966, 'Judaism in Egypt', in L.W. Barnard (ed.), Studies in the Apostolic Fathers and their background, pp. 52-55, Schocken, New York.

Barrett, N.C., 2011, 'The Alexandrian Catechetical School of Clement and Origen as a postmodern model for the contemporary church and theological academy', MA thesis in Religion, Hardin-Simmons University.

Bauer, W., 1971, Orthodoxy and heresy in earliest Christianity, English transl. RA. Kraft \& G. Krodel (eds.), Fortress, Philadelphia.

Baur, J., 1994, 2000 years of Christianity in Africa, Paulines, Nairobi.

Becker, A.H., 2003, 'Beyond the spatial and temporal limes: Questioning the "Parting of the ways" outside the Roman Empire', in A.H. Becker \& A.Y. Reed (eds.), The ways that never parted, pp. 373-392, Mohr Siebeck, Tübingen.

Bennett, R.A., 1971, 'Africa and the biblical period', Harvard Theological Review 64(4), 483-500. http://dx.doi.org/10.1017/S0017816000023403

Blakstad, O., 2008, Research methodology: Key concepts of the scientific method, viewed 07 September 2012, from http://www.experiment-resources.com/ research-methodology.html

Boyarin, D., 2003, 'Semantic differences; or "Judaism"/“Christianity"', in A.H. Becker \& A.Y. Reed (eds.), The ways that never parted, pp. 65-85, Mohr Siebeck, Tübingen. Burton, K.A., 2007, The blessing of Africa, InterVarsity Press, Downers Grove.

Busha, C. \& Harter, S.P., 1980, Research methods in librarianship: Techniques and interpretations, Academic Press, New York.

Cohen, S.J.D., 2006, From the Maccabees to the Mishnah, 2nd edn., Westminster John Knox Press, Louisville.

Coptic Orthodox Church Network, n.d., An introduction to the School of Alexandria, viewed 03 April 2012, from http://www.copticchurch.net/topics/patrology/ schoolofalex/I-Intro/chapter1.html

Darkwah, N.B., 2005, The Africans who wrote the Bible, Aduana Publishing, White Plains.

eAlmanac, n.d., Two-thirds World, viewed 05 October 2012, from http://www ealmanac.com/2177/numbers/two-thirds-world/

Eisenman, R., 1996, The Dead Sea Scrolls and the first Christians. Essays and translations, Element Books, Shaftesbury.

Ellison, H.L., 1978, 'Judaism', in J.D. Douglas (ed.), The new Bible dictionary, pp. 631634, Inter-Varsity Press, Leicester.

Enslin, M.S., 1954, 'A gentleman among the fathers', The Harvard Theological Review 47(4), 213-241. http://dx.doi.org/10.1017/S0017816000024962

Fogarty, M.E., 2004, 'Egyptian Christianity: An historical examination of the belief systems prevalent in Alexandria C.100 BCE - 400 CE', unpublished MPhil dissertation, Department of Ancient Near Eastern Studies, University of Stellenbosch.

Frend, W.H.C., 1983, 'Early Christianity and society: A Jewish legacy in the preConstantinian era', Harvard Theological Review 76(1), 53-71. http://dx.doi. org/10.1017/S0017816000018460

Frend, W.H.C., 1992, The early church: From the beginnings to 461 , 3rd edn., Billing \& Sons Ltd, Worcester.

Georgi, D., 1995, 'The Early Church: Internal Jewish migration or new religion?', Harvard Theological Review 88(1), 35-68. http://dx.doi.org/10.1017/ S0017816000030388

Goldenberg, R., 2002, 'Review of Boyarin, D. 1999. “Dying for God: Martyrdom and the making of Christianity and Judaism"', The Jewish Quarterly Review, New Series 92(3/4), 586-588.

Gonzalez, J.L., 1984, The story of Christianity, vol. 1, The early Church to the dawn of the Reformation, Harper, San Francisco.

Groves, C.P., 1948, The planting of Christianity in Africa, vol. 1, To 1840, Lutterworth Press, London.

Harris, C.V., 1966, Origen of Alexandria's interpretation of the teacher's function in the early Christian hierarchy and community, The American Press, New York.

Hillerbrand, H.J., 2012, A new history of Christianity, Abingdon Press, Nashville.

Isichei, E.A., 1995, A history of Christianity in Africa, William B. Eerdmans, Grand Rapids.

Jacobs, A.S., 2003, 'The lion and the lamb: Reconsidering Jewish-Christian relations in Antiquity', in A.H. Becker \& A.Y. Reed (eds.), The ways that never parted, pp. 95-118, Mohr Siebeck, Tübingen. 
Kovacs, J.L., 2009, 'Clement (Titus Flavius Clemens) of Alexandria', Expository Times 120(6), 261-271. http://dx.doi.org/10.1177/0014524608101840

Linsley, A.C., 2010, Abraham's ancestors came out of Africa, viewed 05 October 2012 from http://jandyongenesis.blogspot.com/2010/06/abrahams-ancestors-cameout-of-africa.html

Lynch, J.H., 2010, Early Christianity: A brief history, Oxford University Press, New York. MacCulloch, D., 2009, Christianity: The first three thousand years, Viking, New York.

McGrath, A.E., 2007, Christianity's dangerous idea: The Protestant revolution - A history from the sixteenth century to the twenty-first, Harper One, New York.

McGrath, A.E., 2013, Christian History: An introduction, Wiley-Blackwell, Chichester.

McLelland, J.C., 1976, God the Anonymous: A study in Alexandrian philosophical theology, Patristic Monography Series 4, The Philadelphia Patristic Foundation, Ltd, Cambridge.

Merriam-Webster, n.d., Sect, viewed 05 October 2012, from http://www.merriamwebster.com/dictionary/sect

New World Encyclopedia, 2012, Coptic Church, viewed 31 March 2014, from http:// www.newworldencyclopedia.org/entry/Coptic_church

Oden, T.C., 2007, How Africa shaped the Christian mind, Inter-Varsity Press, Downers Grove.

Otzen, B., 1998, Judaism in Antiquity. Political development and religious currents from Alexander to Hadrian, JSOT Press, Sheffield.

Pearson, B.A., 1986, 'Christians and Jews in first-century Alexandria', Harvard Theological Review 79(1-3), 206-216. http://dx.doi.org/10.1017/ S0017816000020472

Pearson, B.A., 1997, The emergence of the Christian Religion. Essays on Early Christianity, Trinity Press International, Harrisburg.

Pheko, S.E.M., 1982, The early Church in Africa (1st to 7th Century) and today, Multimedia Publications, Lusaka.

Reed, A.Y., 2003, “'Jewish Christianity" after the "Parting of the ways": Approaches to historiography and self-definition in the Pseudo-Clementines', in A.H. Becker \& A.Y. Reed (eds.), The ways that never parted, pp. 189-231, Mohr Siebeck, Tübingen.

Roberts, A. \& Donaldson, J. (eds.), 2004, 'Clement of Alexandria', in P. Schaff (ed.), Fathers of the second century: Hermas, Tatian, Athenagoras, Theophilus, and Clement of Alexandria, vol. 2, Ante-Nicene Fathers, n.p., Hendrickson Publishers, Inc., Peabody.
Robinson, T.A., 2009, Ignatius of Antioch and the parting of the ways: Early JewishChristian relations, Hendrickson Publishers, Inc., Peabody.

Schaff, P., 1885a, Fathers of the Second Century: Hermas, Tatian, Athenagoras, Theophilus, and Clement of Alexandria (Entire), vol. 2, Ante-Nicene Fathers, Christian Classics Ethereal Library, Grand Rapids.

Schaff, P., 1885b, Gregory Thaumaturgus; Dinoysius the Great; Julius Africanus; Anatolius and Minor Writers; Methodius; Arnobius, vol. 6, Ante-Nicene Fathers, Christian Classics Ethereal Library, Grand Rapids.

Schaff, P., 1910, History of the Christian Church, Eerdmans, Grand Rapids.

Schneider, W., 2009, How long did the Hebrews live in Egypt?, viewed 14 September 2012, http://www.biblecenter.de/bibel/widerspruch/e-wds14.php

Scholten, C., 1995, 'Die alexandrinische Katechetenschule', Jahrbuch für Antike und Christentum 38, 16-37.

Shathaya, G.H., 1999, Who are the Chaldeans?, viewed 04 October 2012, from http:// www.chaldeansonline.org/chald.html

Stanley, A.P., 1883, Lectures on the history of the Eastern Church: With an introduction on the study of ecclesiastical history, John Murray, London.

Stark, R., 1997, The rise of Christianity, Princeton University Press, Princeton.

Tcherikover, V.A., 1963, 'The decline of the Jewish Diaspora in Egypt in the Roman period', Journal of Jewish Studies 14, 1-32.

Van den Broek, R., 1995, 'The Christian "School" of Alexandria in the second and third centuries', in J.W. Drijvers \& A.A. MacDonald (eds.), Centres of learning: Learning and location in pre-modern Europe and the Near East, pp. 39-47, Brill, Leiden.

Van den Broek, R., 1996, Studies in Gnosticism and Alexandrian Christianity, Nag Hammadi and Manichaean Studies 39, Brill, Leiden.

Van den Hoek, A., 1997, 'The "Catechetical" School of Early Christian Alexandria and its Philonic heritage', Harvard Theological Review 90(1), 59-87. http://dx.doi. org/10.1017/S0017816000006180

Von Harnack, A., 1915, Die Mission und Ausbreitung des Christentums in den ersten drei Jahrhunderten, vol. 1, 3rd edn., J.C. Hinrichs, Leipzig.

Vrettos, T., 2001, Alexandria: City of the Western mind, The Free Press, New York.

Winters, C.A., 2010, 'The Kushite spread of Haplogroup R1*-M173 from Africa to Eurasia', Current Research Journal of Biological Sciences 2(5), 294-299. 